\title{
Adherence to lung cancer surgical quality standards is critical for the survival of both our patients and our specialty
}

\author{
Robert B. Cameron, MD
}

\footnotetext{
From the Division of Thoracic Surgery, Department of Surgery, David Geffen School of Medicine at UCLA, Los Angeles, Calif; and the Division of Thoracic Surgery, Department of Surgery and Perioperative Care, West Los Angeles VA Medical Center, Los Angeles, Calif.

Disclosures: Author has nothing to disclose with regard to commercial support.

Received for publication Feb 26, 2018; accepted for publication Feb 28, 2018; available ahead of print Apr 13, 2018

Address for reprints: Robert B. Cameron, MD, Division of Thoracic Surgery, Department of Surgery, David Geffen School of Medicine, 10780 Santa Monica Blvd, Suite 100, Los Angeles, CA 90025 (E-mail: rcameron@ stanfordalumni.org).

J Thorac Cardiovasc Surg 2018;156:392-3

$0022-5223 / \$ 36.00$

Copyright (c) 2018 by The American Association for Thoracic Surgery

https://doi.org/10.1016/j.jtcvs.2018.02.071
}

Lung cancer surgery, for now, accounts for a large proportion of many thoracic surgeons' clinical practice. Recent data estimate that 234,030 new lung cancers will be diagnosed in the United States in 2018. Thirty-eight percent of patients $(88,931)$ are diagnosed with local or locoregional disease potentially amenable to surgical resection. ${ }^{1,2}$ These numbers may increase even more in the future with broader lung cancer screening availability. ${ }^{3}$

Previously, surgical resection was the unquestioned primary treatment option for all patients with early-stage, medically operable lung cancer. Yet over the last 2 decades, development of image-guided thermal ablation and stereotactic radiation therapy (SRT) for medically inoperable patients has created therapies that now are challenging surgery as viable treatment options for operable patients as well. ${ }^{4-6}$ Although 3 randomized trials comparing SRT with surgery failed because of poor accrual, the ongoing Veterans Affairs Lung Cancer Surgery Or Stereotactic Radiotherapy ([VALOR]; NCT02984761) Trial is accruing at an acceptable rate and will continue until 2026 (Drew Moghanaki, MD, 2018; personal communication). In the meantime, patients with operable early-stage lung cancer already are being referred for SRT without surgical consultation. In one study, 11 of 37 propensity-matched patients $(29.7 \%)$ "refused surgery" or "sought primary SBRT as a 'preferable' treatment." 7 Another study noted increased use of SRT ( $2 \%$ in 2006 to $19 \%$ of all treatments in 2015 ) with the 449 reported patients undergoing SRT having less comorbidity than comparable patients undergoing sublobar surgery, also intimating that surgical candidates were bypassing surgeons for SRT.

Ajmani and colleagues ${ }^{8}$ highlight a critical issue, surgical quality variability, particularly in nodal staging and margin status, which plausibly may explain inconsistencies in reported outcomes comparing surgery with SRT. Historically, invasive surgical staging has been inconsistent at best. Little and colleagues ${ }^{9}$ reported that mediastinoscopy

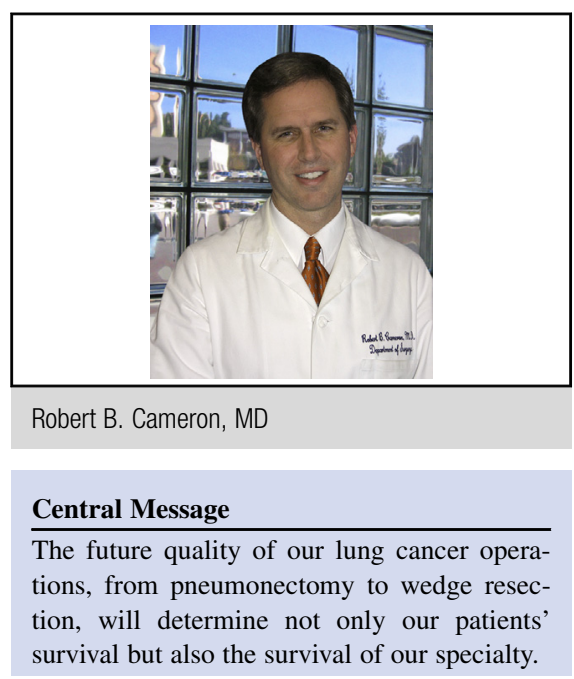

See Article page 380

See Editorial page 376.

was performed in only $27.1 \%$ of operated patients, and in more than half of mediastinoscopies, no lymph nodes were even biopsied. ${ }^{9}$ Even with the recent addition of endobronchial ultrasound, $88 \%$ of patients in a community healthcare setting had no invasive preoperative staging. ${ }^{10}$ In 7734 propensity-matched patients from the National Cancer Database, Ajmani and colleagues ${ }^{8}$ demonstrate that patients treated with wedge resection who had high surgical quality as measured by margin status (negative) and lymph nodes examined $(>5)$ had superior survival compared with patients who received stereotactic body radiotherapy (log-rank $P<.001)$, maintaining a lower hazard of death in multivariable analysis (adjusted hazard ratio, $0.66 ; 95 \%$ confidence interval, 0.61-0.70) despite higher comorbidity and larger tumors. Although retrospective with relatively small numbers in the high-quality and upstaged groups and a disturbingly large number of wedge over anatomic resections performed $(10,032)$, the findings nonetheless are compelling and consistent with similar prior sublobar analyses. ${ }^{11}$

To avoid being bypassed altogether in the future, thoracic surgeons, now more than ever, must engage in performing consistent high-quality surgery, including detailed lymph node dissection and clear margins. As suggested by Ajmani and colleagues, ${ }^{8}$ if we, as thoracic surgeons, fail to maintain the highest quality, surgical outcomes will fall short of 
demonstrating clear benefit over SRT, and in the absence of clear benefit, SRT mistakenly will become the primary treatment option for early-stage lung cancer, with surgery reserved only as salvage therapy.

\section{References}

1. Siegel RL, Miller KD, Jemal A. Cancer statistics, 2018. CA Cancer J Clin. 2018; 68:7-30.

2. Siegel RL, Miller KD, Jemal A. Cancer statistics, 2017. CA Cancer J Clin. 2017; 67:7-30.

3. Henschke CI, McCauley DI, Yankelevitz DF, Naidich DP, McGuinness G, Miettinen OS, et al. Early lung cancer action project: overall design and findings from baseline screening. Lancet. 1999;354:99-105.

4. Tandberg DJ, Tong BC, Ackerson BG, Kelsey CR. Surgery versus stereotactic body radiation therapy for stage I non-small cell lung cancer: a comprehensive review. Cancer. 2018;124:667-78.

5. Bryant AK, Mundt RC, Sandhu AP, Urbanic JJ, Sharabi AB, Gupta S, et al. Stereotactic body radiation therapy versus surgery for early lung cancer among US veterans. Ann Thorac Surg. 2018;105:425-31.
6. Mouli SK, Kurilova I, Sofocleous CT, Lewandowski RJ. The role of percutaneous image-guided thermal ablation for the treatment of pulmonary malignancies. AJR Am J Roentgenol. 2017;209:740-51.

7. Cornwell LD, Echeverria AE, Samuelian J, Mayor J, Casal RF, Bakaeen FG, et al. Video-assisted thoracoscopic lobectomy is associated with greater recurrencefree survival than stereotactic body radiotherapy for clinical stage I lung cancer. J Thorac Cardiovasc Surg. 2018;155:395-402.

8. Ajmani GS, Wang CH, Kim KW, et al. Surgical quality of wedge resection impacts overall survival in patients with early stage non-small cell lung cancer. $J$ Thorac Cardiovasc Surg. 2018;156:380-91.

9. Little AG, Rusch VW, Bonner JA, Gaspar LE, Green MR, Webb WR, et al. Patterns of surgical care of lung cancer patients. Ann Thorac Surg. 2005;80: 2051-6.

10. Faris N, Yu X, Sareen S, Signore RS, McHugh LM, Roark K, et al. Preoperative evaluation of lung cancer in a community health care setting. Ann Thorac Surg. 2015;100:394-400

11. Samayoa AX, Pezzi TA, Pezzi CM, Greer Gay E, Asai M, Kulkarni N et al. Rationale for a minimum number of lymph nodes removed with non-small cell lung cancer resection: correlating the number of nodes removed with survival in 98,970 patients. Ann Surg Oncol. 2016;23(Suppl 5):1005-11. 